\title{
Digital storytelling as a disciplinary literacy enhancement tool for EFL students
}

\author{
Nadezhda Chubko ${ }^{1}$ (D) . Julia E. Morris ${ }^{1}$. David H. McKinnon ${ }^{1}$ - Eileen V. Slater ${ }^{1}$. \\ Geoffrey W. Lummis ${ }^{1}$
}

Accepted: 28 September 2020 / Published online: 13 October 2020

(c) The Author(s) 2020

\begin{abstract}
This research compared the process of disciplinary literacy acquisition of students who experienced two different pedagogical approaches to learning science, technology, engineering and mathematics through astronomy (STEM-A). The objective of this study was to explore the impact of a digital storytelling (DST) educational technology intervention in a STEM-A context on the process of disciplinary literacy acquisition of students who were learning English as a foreign language (EFL). The research was designed as a type IV case study with a sample of 30 students from Kyrgyzstan aged between 12 and 16 years. Data were collected from written responses to the astronomy diagnostic tests (ADT), which were coded against the structure of the observed learning outcomes (SOLO) and analysed using the analysis of variance (ANOVA) with repeated measures on the occasion of testing. Data from the Australian sample, native speakers of English, $(\mathrm{N}=328)$ were used as a baseline. The results showed a positive effect of the DST intervention on EFL students' astronomy disciplinary literacy acquisition. The research contributes to the body of knowledge on educational technology by exemplifying how the DST teaching intervention could bridge the gap between EFL and non-EFL students' disciplinary literacy acquisition in STEM areas.
\end{abstract}

Keywords Astronomy · Digital storytelling (DST) $\cdot$ Disciplinary literacy $\cdot$ English as a foreign language $(\mathrm{EFL}) \cdot$ Science $\cdot$ technology $\cdot$ engineering and mathematics (STEM) · Videomaking

Nadezhda Chubko

nchubko@our.ecu.edu.au; cnadia@list.ru

Julia E. Morris

j.morris@ecu.edu.au

David H. McKinnon

d.mckinnon@ecu.edu.au

Eileen V. Slater

e.slater@ecu.edu.au

Geoffrey W. Lummis

g.lummis@ecu.edu.au

1 School of Education, Edith Cowan University, Perth, Australia 


\section{Introduction}

Whereas reported educational statistics show a gap between non-native (EFL) and native (non-EFL) English speakers' literacy and numeracy test performance (Department of the Prime Minister and Cabinet 2018; National Assessment Program 2015; The Nation's Report Card 2015), recent research in linguistics underscores the misleading nature of such comparisons. While native speakers as a group usually outperform non-native speakers (Somers 2017; Fleckenstein et al. 2016), there is high intragroup variability (Dąbrowska 2019; Hulstijn 2019). EFL students' proficiency in social, economic and academic English literacy makes them competitive against native English speakers in the global job market (Fleckenstein et al. 2016). Consequently, most of the differences in academic performance observed in both native and EFL speakers can be attributed to education (Dąbrowska 2019).

This research sought to explore pedagogical practices that could bridge the gap in native and EFL speakers' disciplinary literacy in science, technology, engineering and mathematics (STEM) disciplines. This is because STEM subjects pose additional challenges for both EFL and non-EFL students. Specifically, the complexity of the academic language and lack of authentic learning experiences frequently prevent students from drawing connections between school and their everyday life (González-Howard and McNeill 2016; GonzálezHoward et al. 2017; Grandinetti et al. 2013; Stevenson 2015; Zhang 2016).

The current Kyrgyzstani study explored how a digital storytelling (DST) or video-production (Angay-Crowder et al. 2013; Rubino et al. 2018) teaching approach might enhance EFL students' learning and promote their astronomy (STEM-A) disciplinary literacy acquisition. It was the extension of the Australian study, the Indigenous Sky Stories (ISS) program, conducted with Australian primary school students aged 10-12 years (Ruddell et al. 2016). In the ISS program, astronomy served as a context for learning where local Indigenous and western scientific perspectives were brought together in the classroom to create a cultural 'middle ground' (Aikenhead 1996; Nakata 2018; Ruddell et al. 2016). This study demonstrated how an integrated curriculum could engage students in scientific inquiry and encourage active shared knowledge construction (Ruddell et al. 2016). The Kyrgyzstani study was conducted with EFL students aged 10-16 years and used the same astronomy teaching materials as the ISS program (Ruddell et al. 2016), but also included a collaborative videomaking educational technology intervention.

This article compares differences in astronomy disciplinary literacy acquisition between Kyrgyzstani students who had DST as part of an educational technology enhanced design with Australian students who completed the same astronomy course intervention, but were not engaged in making videos. The guiding research questions for this analysis were: Does DST influence the EFL students' astronomy disciplinary literacy development in English? If "yes", how does this happen?

\section{Bridging literacy and science education}

Several decades of studying the role of a language in learning and teaching across various content areas have resulted in a 'cross-border dialogue' that bridges literacy and science education research internationally (Díaz Pérez et al. 2018; Fujimoto-Adamson and Adamson 2018; Morton 2018; Tang et al. 2018). The acknowledgment of the role of disciplinary literacy in science triggered the emergence of English for Specific Purposes 
(ESP) courses. ESP courses required English language teachers to deliver STEM content-related English (Yang 2016). However, language teachers struggled with adopting this approach as they did not have enough understanding of the disciplinary discourse related to the subject content knowledge (Arno-Macia and Mancho-Bares 2015; Morton 2018).

Consequently, Content and Language Integrated Learning (CLIL) programmes emerged. Initially, CLIL programmes were responding to the needs of the globalised job market and addressed the growing diversity of students in modern classrooms around the globe (Madrid and Cañado 2018; Yang 2016). It resulted in CLIL becoming a broad term referring to any classroom setting where a subject was taught in a language other than the students' native language (Díaz Pérez et al. 2018; Yang 2016). CLIL programmes were readily embraced in North America and many European countries (Tang et al. 2018; Yang 2016) and enabled the content instructors in these countries to adopt the teaching approaches developed by the language instructors (Díaz Pérez et al. 2018; Jendrych 2013).

In general, CLIL research has reported positive outcomes (Somers 2017). However, a recent large-scale CLIL program evaluation in Spain revealed a lack of key egalitarianism or social inclusion principals essential to CLIL education (Cañado 2018). CLIL materials and teaching resources were also criticised for their lack of authenticity and scarce integration of technology (Cañado 2018), highlighting the importance of inclusiveness and authenticity in teaching content knowledge to EFL students (Cañado 2018; Darío 2014).

\section{Disciplinary literacy in science as a social practice}

One of the main criticisms of science lessons is that students can not establish a link between lessons and their everyday real life contexts (Aikenhead 1998; González-Howard and McNeill 2016; Meyer and Crawford 2015). Conventional science education usually adheres to didactic or knowledge transmission pedagogies and does not prioritise students' engagement in learning (González-Howard and McNeill 2016; González-Howard et al. 2017; Haydock 2011; Meyer and Crawford 2015; Zhang 2016), whereas research suggests that EFL students' literacy development requires students to question their current knowledge and extend and adapt it to other contexts (Angay-Crowder et al. 2013).

The interdisciplinary collaboration encouraged by the CLIL programmes faciliatated a shift towards the recognition of literacy as a 'form of social practice' rather than the linguistic medium for delivering scientific concepts to students (Díaz Pérez et al. 2018; Tang et al. 2018). Recognising disciplinary literacy as a sociocultural phenomenon implies that learning is the outcome of engagement in various activities contextualised within social settings. Tytler et al. (2018) argue that science literacy development requires students to explore diverse representations of scientific concepts. By creating and critiquing various representations of science concepts such as a model to represent the cause of day and night, students develop a meta-representational competence and deepen their awareness about the concept (Tytler et al. 2018).

When working in groups, students exchange their interpretations of a given phenomenon and thus construct shared knowledge (Van Aalst 2009). Hence, social interactions and ongoing negotiation of concepts within the 'community of practice' results in a deeper understanding of a concept (Lave and Wenger 1991; Mercieca 2017; Wegner and Nückles 2015). 


\section{Indigenous sky stories project}

The Journey through Space and Time (JTST) resource package was designed as a remedy for disengaged primary school students and their teachers in learning science (McKinnon and Geissinger 2002). This educational package (McKinnon 2013) contained support resources for teaching astronomy, differentiated for teachers' diverse experience and content knowledge in the area. The JTST became the key component for the Australian educational project Indigenous Sky Stories (ISS) (Ruddell et al. 2016). Besides supplying the participating schools with an 8-inch reflecting telescope, an iPad mini with preinstalled Stellarium planetarium software, inquiry-based learning and teaching resources, and professional training with ongoing support for the teachers to assist with project implementation, ISS also provided access to an Aboriginal storyteller to share Indigenous stories about the sky (Ruddell et al. 2016). The school and community collaboration encouraged students to share their own sky stories that they had learned from their families. The analysis of students' interviews showed that their participation in this ISS project allowed them to establish strong connections between their cultural stories and concepts presented in western science (Ruddell et al. 2016).

Participation in the ISS project resulted in students' attainment of the curricular goals combined with gaining a first-hand learning experience and developing a scientific understanding of the real-life phenomena (McKinnon and Geissinger 2002). Additionally, engagement with this project helped students to identify and replace their alternative conceptions about various astronomy phenomena. The scaffolding activities allowed students to comprehend more advanced mathematical concepts such as scale models (McKinnon and Geissinger 2002).

\section{Digital storytelling and science disciplinary literacy development}

Advances in technology have led to the digitalisation of storytelling and have resulted in the emergence of digital storytelling (DST), a multi-literacy practice of storytelling mediated by digital tools. In most cases DST results in the creation of a video output (AngayCrowder et al. 2013; Castañeda et al. 2018; Ohler 2013; Rubino et al. 2018; Teehan 2006; Zellner 2018). Zellner (2018) piloted a DST intervention with her college students enrolled in an introductory astronomy course. Participation in this intervention empowered them to assume ownership of their learning process because they could explore the astronomical topics that aligned with their personal interests (Smith et al. 2018). Zellner (2018) reported that the DST intervention supported her students' development of creativity and extended their astronomy content knowledge. Additionally, Zellner's students developed additional skills that were transferrable beyond the astronomy disciplinary context, for example collaboration and use of technology.

The integration of DST in various formal educational contexts, including Kindergarten-Grade 12, higher education and professional education (Rossiter and Garcia 2010; Rubino et al. 2018) has highlighted that DST interventions facilitated collaborative writing for all students, including EFL/ESL students (Angay-Crowder et al. 2013; Papadopoulou and Vlachos 2014; Rubino et al. 2018). DST creates a middle ground for EFL students to explore and combine their multiple literacies and social identities (Angay-Crowder et al. 2013) enhanced through multiple representations. For example, making videos about scientific phenomena creates a context for a disciplinary discourse and, with careful guidance, 
could facilitate and maintain students' science disciplinary literacy development (Bell et al. 2009).

Despite some early evidence of successful learning outcomes and positive experiences in reported interventions (Pirbhai-Illich 2010; Pirbhai-Illich et al. 2009), DST is still an emerging trend in STEM education. Teachers remain cautious about including DST in their classroom practices because of curriculum and time constraints (Pirbhai-Illich et al. 2009). However, the well-planned integration of videomaking projects does not take significant time away from curriculum implementation and has a positive impact on students' learning (Morgan 2015; Zellner 2018) as evidenced by the concomitant reports of improvement in students' presentation and writing skills (Niemi et al. 2018).

Other research also highlights the potential of DST for integrating multiple disciplines so that students could develop their higher order thinking skills (Anderson et al. 2018). Additionally, Anderson et al. (2018) emphasise that DST is effective in drawing students' attention to their language use while being engaged in the creation and sharing of their personalised stories (Andersone et al. 2018). However, there is a gap in understanding the impact of DST on the development of foreign or community languages as most DST research has been conducted in students' mother tongue, usually English (Anderson et al. 2018).

Therefore, there is a need to further explore the role of DST in multilingual contexts, with the overarching goal of developing students' STEM-A disciplinary literacy in English. This need has emerged from problems related to students' language development (Anderson et al. 2018) exacerbated by the increasing role of English in STEM areas (Plo-Alastrué et al. 2015) as well as the economic divide between EFL and non-EFL speakers (Fleckenstein et al. 2016). Previous research has shown a positive impact of DST in teaching astronomy (Ruddell et al. 2016; Zellner 2018). Therefore, this research sought to explore the impact of DST on disciplinary literacy acquisition of EFL astronomy students.

\section{Method}

Adopting Yin's (2014) research design classification, this project was conducted as a type IV embedded multiple-case study. Embedded designs involve multiple units of analysis, including quantitative and qualitative measures derived from students' tests and field notes (Yin 2014). Such designs also use multiple cases. In this investigation there were two cases: an Australian case (Case 1) and a Kyrgyzstani case (Case 2). The focus of each of these cases was slightly different. The aim of the Australian case was to improve nonEFL students' astronomy content knowledge and the aim of the Kyrgyzstani case was to improve EFL students' astronomy disciplinary literacy. However, there are three reasons why comparisons can be made. First, both cases used the same content in their intervention (outlined in research background). Second, they used the same instrumentation to measure students' content knowledge (outlined in data collection instrumentation). Third, the length of the intervention (in hours) was similar between the two cases (outlined in research background).

There were also two key differences between the cases that allowed using the data from the Australian case as a baseline data. First, unlike the Australian case, the Kyrgyzstani case enhanced the intervention with DST. Second, there was a difference in participants' language background: the Australian study included non-EFL learners, but the Kyrgyzstani participants were all EFL learners. Consequently, analysis of the two cases was conducted 
to answer the research questions: Does the DST approach influence the EFL students' STEM-A disciplinary literacy development in English? If "yes", how does this happen?

\section{Research background}

Both cases used resources from the JTST educational package (McKinnon 2013), which was developed within a constructivist theoretical framework to encourage students' learning through active inquiry (McKinnon 2013). This resource package was developed to support Australian primary and secondary teachers and therefore was aligned with the Australian science curriculum standards (Australian Curriculum, Assessment and Reporting Authority [ACARA] 2018).

The data for the first case study (Case 1) was extracted from the Western Australian research project known as Cultural Sky Stories (CSS), which is an extension of the ISS project (Ruddell et al. 2016). The aim of CSS was to improve the astronomy content knowledge of students, aged 10-12 years, by integrating culturally-grounded knowledge (including Indigenous stories) with western scientific understandings about the sky (Slater et al. 2018). In this integrated approach, the emphasis was on creating a cultural middle ground to engage a diverse range of students in learning science (Aikenhead 1996; Nakata 2018).

The Kyrgyzstani case (Case 2) also used the JTST astronomy package (McKinnon 2013) to explore how a DST pedagogical approach might promote STEM-A disciplinary literacy acquisition in a foreign language. The study was conducted with students aged 10-16 years in both an educational centre and in regular school settings through extracurricular courses. While all Case 2 participants experienced engagement with DST, there were a number of embedded cases where the intervention processes were refined during the research.

Kyrgyzstani embedded case studies were conducted in two research sites: educational centre (Groups 1-3) and a school (Group 4). The intervention for Groups 1 and 2 started with the exploration of the scale models of the Solar System and concluded with the exploration of the reasons for day and night, Moon phases, and seasons. Groups 3 and 4, experienced the reversed course sequence, which started with the exploration of the reasons for day and night, Moon phases, and seasons, and then completed with the exploration of the Solar System and the construction of scale models. Consequently, throughout the course, Groups 1 and 2 were focused on making videos about the individual planets of the Solar System, using various Internet resources as their references, while Groups 3 and 4 were making videos about Moon phases with their videos based on the knowledge and experience they gained through exploration and inquiry. The Australian students were not involved in DST, but they participated in the same inquiry activities as Kyrgyzstani sudents. For the Australian case the JTST was integrated into their regular science lessons at school and sequenced in the same way as for Kyrgyzstani Groups 1 and 2.

Australian participants from the CSS project (Slater et al. 2018) worked through the JTST astronomy package (McKinnon 2013) for approximately two hours per week over one school term (i.e., approximately 20 h). Based on a 2017 Kyrgyzstani pilot (Chubko et al. 2019), the length of intervention lessons for the Kyrgyzstani participants (Case 2) was reduced from 150 to $120 \mathrm{~min}$ implemented over 10 days to fit with other extracurricular courses provided by the participating educational centre. Consequently, both the Australian and the Kyrgyzstani interventions were $20 \mathrm{~h}$ in length.

All four groups in Kyrgyzstan were taught by the first author who received the same professional development as the classroom teachers participating in CSS (Slater et al. 
2018) who delivered the astronomy course in Australia. Additionally, the teacher for the Kyrgyzstani case (Case 2) had a Teaching English to the Speakers of Other Languages (TESOL) qualification. Prior to the intervention, the first author received training in DST and the use of video-editing software, including iMovie (the video editor used for this intervention).

\section{Sample}

The sample for this analysis comprised 30 Kyrgyzstani students who learned English as a foreign language (EFL) and 325 non-EFL Australian students. Groups 1-3 from Kyrgyzstan spoke Russian as their first language (L1), while the majority of students from Group 4 used Kyrgyz as their L1. The teacher (first author) was fluent in Russian, but she had only a basic proficiency in Kyrgyz. The Kyrgyzstani sample contained two participants from Group 1 who could speak only Russian. The other Kyrgyzstani participants' (28) level of English proficiency ranged from elementary (A2-B1) to intermediate (B1-B2) according to the Common European Framework of Reference for Languages (Council of Europe, 2018). Groups 1-3 had access to online dictionaries on their personal mobile devices or the mini-iPads provided by the teacher throughout the course. Group 4 could not use their personal mobile devices and did not have any internet connection on the mini-iPads provided by the teacher during the course because of restricted access to the internet in the school.

The first three groups from Kyrgyzstan (Groups 1-3) were mixed-gender groups enrolled in the same educational centre and were taught on the same premises during the summer vacation in 2018. Group 4 were female students enrolled in a Muslim school with separate classes for boys and girls. The girls were invited by their school principal to join the after-school astronomy course in October, 2018, during the first term of the school year. The Australian students were recruited from four mixed-gender schools. While it is likely that some students in this sample were multilingual, their schooling was conducted in English and students were considered to have English as their L1. The Australian sample is labelled as Group 5.

The participants from both countries were aged between 10 and 16 years. In addition to being engaged with inquiry activities about astronomy from the JTST (McKinnon 2013), all four groups from Kyrgyzstan were exposed to the DST intervention that required the students to participate in making videos in English about the astronomy concepts they were learning during the course.

Informed consent Informed consent was obtained from all individual participants included in the study as well as from their parents as required by the Ethics in Human Research Committee at the university where the first author was enrolled as a $\mathrm{PhD}$ student.

\section{Data collection instruments}

Textual data were collected from the written responses to the Astronomy Diagnostic Test (ADT) included in the JTST resource package (McKinnon 2013), which was administered at the beginning and again at the end of the course. That is to say, the design was a repeated measures pre-post enterprise. All Kyrgyzstani students and most of the Australian students $(\mathrm{N}=200)$ completed the 15 -question version of the ADT. However, the rest of the Australian sample completed a slightly shorter 11-question version with four of the 15 questions being removed. In both versions, the first four questions asked students to draw a picture to explain a particular phenomenon and to write their reasoning for their answer. 
The remaining questions asked students to select their answer from multiple-choice options and to write their reasoning for selecting each answer.

Importantly, as the aim of this research was to identify the shift in EFL students' astronomy disciplinary literacy in English, Kyrgyzstani groups were not directly instructed to use English when providing reasons for their answers to the ADT questions. It was assumed that by giving EFL students the choice of language it would enhance the authenticity of their argumentation rather than drawing their attention to language. Additional data from the Kyrgyzstani sample also included a number of videos produced by the students in the DST approach and the researcher's field notes.

\section{Data analysis}

Due to the significant difference between Australian (325) and Kyrgyzstani (30) sample sizes, an Analysis of Variance (ANOVA) with repeated measures on the occasion of testing was computed using Group membership as the independent variable to test the ability to compare these two groups. To verify that the distributions of the data met the mathematical assumptions of the statistical approach, the homogeneity of the covariance matrices was computed to ensure that both the individual and joint distributions of the groups were normally distributed. Box's test of the equality of the covariance matrices was used to test the null hypothesis that the observed covariance matrices of the dependent variables were equal across groups. The Box's M statistic was not significant (Box's $M=16.309, F$ $(12,1739.32)=1.170, p=0.299)$; thus, statistical results could be interpreted with confidence despite the difference in sample sizes.

The written responses provided by the students were assessed against the Structure of the observed learning outcome (SOLO) taxonomy (Biggs and Collis 1982). The coding employed was: ' 1 ' for a response at the pre-conceptual level of thinking; ' 2 ' for a unistructural response; ' 3 ' for a multistructural response; ' 4 ' for a response establishing relationships among the components of a concept; and ' 5 ' for a response related to a bigger idea or an overarching theory. If no entry was made a response was scored as a ' 0 '.

Both versions of the ADT test had four questions about Moon phases. Groups 3 and 4 of Kyrgyzstani case made videos about the Moon phases, while the other Kyrgyzstani participants did not make videos about the Moon phases. Therefore, the analysis examined students' written responses to these four questions alone to investigate any differential effects of the DST intervention on EFL students' disciplinary literacy development in English.

Consequently, a scale of SOLO performance was investigated for reliability. Cronbach's alpha on the pre-occasion of testing was 0.649 . On the post-occasion, Cronbach's alpha was 0.740 . The analysis showed that the four items could be added to produce a summed scale. Tukey's estimate of the power to which observations should be raised to achieve additivity was 0.906 . This value is close enough to 1 to allow the individual scores to be added without further mathematical transformation. The higher value of Cronbach's alpha on the post-occasion of testing is not surprising given that the students had investigated aspects of the phenomenon and knew more about what causes Moon phases. Analysis of the data was conducted using the Statistical Package for Social Sciences (SPSS) version 23.

Since there were a few Kyrgyzstani students who provided some or all of their written answers in Russian, and the focus of this research was on the disciplinary literacy in English it was decided that the responses in Russian could be assigned a very small value of 0.0001 that had a minimal effect on the mean scores employed in the repeated measures 
Table 1 Pre- and Post- ADT SOLO total mean scores for the four Moon phases questions

\begin{tabular}{lllllll}
\hline & \multicolumn{3}{l}{ Pre-test } & & \multicolumn{2}{l}{ Post-test } \\
\cline { 6 - 7 } Group & $\mathrm{N}$ & Mean & Std. deviation & & Mean & Std. deviation \\
\hline Group 1 & 5 & 3.20 & 4.324 & 3.60 & 3.361 \\
Group 2 & 8 & 2.75 & 2.549 & & 2.87 & 2.949 \\
Group 3 & 5 & 3.40 & 3.715 & & 6.20 & 3.271 \\
Group 4 & 12 & 2.75 & 3.361 & & 6.50 & 4.482 \\
Group 5 & 328 & 3.74 & 2.705 & & 4.52 & 2.864 \\
Grand means & 358 & 3.67 & 2.757 & & 4.56 & 2.965 \\
\hline
\end{tabular}

Table 2 Summary output of the ANOVA with repeated measures by Group membership

\begin{tabular}{lllllrr}
\hline Source & Occasions & $\begin{array}{l}\text { Type III sum of } \\
\text { squares }\end{array}$ & df & Mean square & F & Sig \\
\hline Occasions & Linear & 50.506 & 1 & 50.506 & 18.720 & 0.00002 \\
Occasions* Group & Linear & 62.998 & 4 & 15.749 & 5.838 & 0.00147 \\
Error (Occasions) & Linear & 952.378 & 353 & 2.698 & & \\
\hline
\end{tabular}

analysis. This was done to maximise the number of cases in the paired analyses in the pre-post design. This small value should not be confused with the ' 0 ' value assigned for a non-response. This approach allowed all of the students' data to be employed in computing a SOLO scale total while simultaneously allowing an analysis of the frequency of Russian language use in their total scores.

\section{Results}

Table 1 shows the mean SOLO scores and standard deviation for each of the five groups on both the pre- and the post-testing occasions. All groups increased their mean SOLO scores for the four questions related to the Moon phases from the pre- to the post-ADT testing occasion (shown in Table 1).

The two Kyrgyzstani groups who made videos about Moon phases (Groups 3 and 4) showed the greatest gains in SOLO mean scores. The remaining two Kyrgyzstani groups (Groups 1 and 2), who did not make videos about the Moon phases, demonstrated lower level gains.

Table 2 shows that there is a significant main effect due to the occasion of testing ( $F(1$, $353)=18.720, p<0.001)$. There is also a significant first-order occasion-by-groups interaction $(F(5,353)=5.838,=p<0.001)$. This interaction indicates that the different groups are behaving in significantly different ways between the pre- and post-test occasions.

In order to interpret the significant first-order interaction between occasion of testing and group membership, the mean scores of each group are plotted in Fig. 1. This shows that Groups 1, 2 and 5 increased their mean scores in a modest fashion while Groups 3 and 4 had much larger gains shown by the steeper gradients.

Figure 1 also shows that the two EFL groups who focused on the Moon phases video production (Groups 3 and 4) outperformed the Australian non-EFL students (Group 5) 


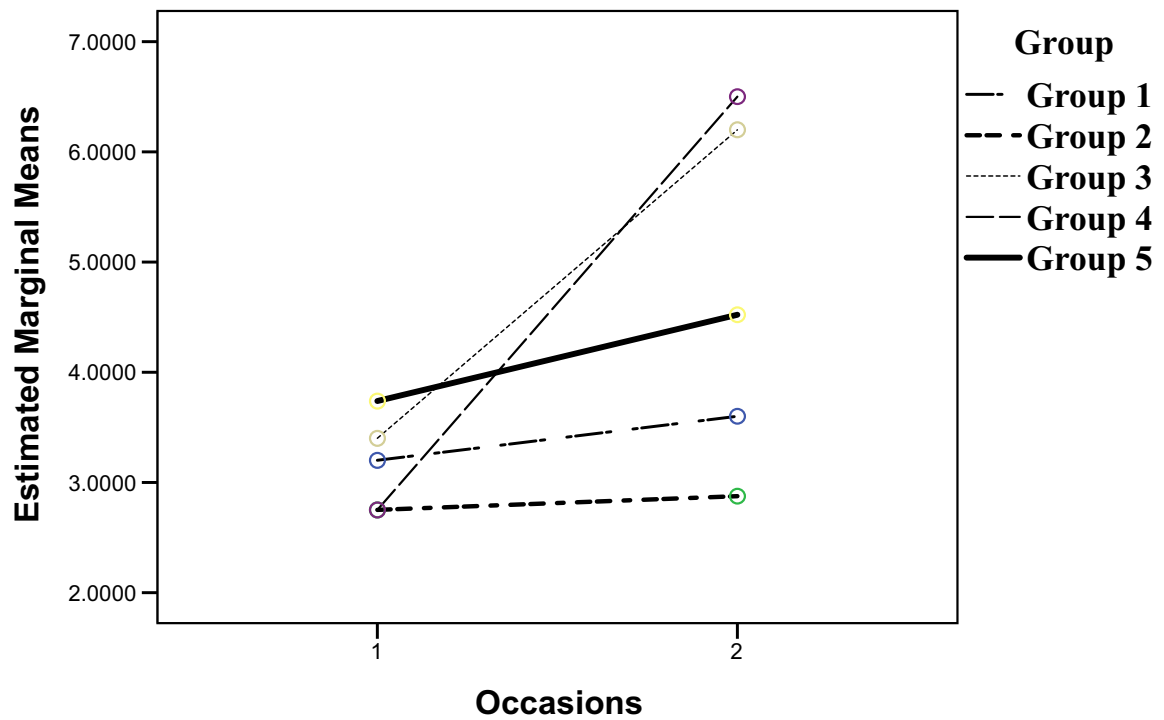

Fig. 1 Pre- and post- ADT SOLO total mean scores for the four Moon phases questions by Group

and the other two EFL groups (Groups 1 and 2) in their ability to express their ideas in English. It is likely that this significant first-order interaction is due to the marked differences in gradients representing the pre- and the post-occasion mean SOLO scores. Importantly, the different treatments appeared to have significant effects on students' ability to explain their reasoning in English, especially when English was not their native language.

As an example, below are the pre- and the post- test answer excerpts of a student who did not make a video about Moon phases (Excerpt 1). Excerpt 2 presents the answer to the same question given by the student who participated in a video production about Moon phases. Both students used Russian to answer this question during the pre-test and then swapped to English in their post-test. Students' entries are included as verbatim transcripts.

While the first student basically translated her earlier idea from Russian to English, the second student adopted the whole new approach to the question as well as

\section{Excerpt 1}

\begin{tabular}{ll}
\hline Pre-test & Post-test \\
\hline Из-за того что луна вращается вокруг Земли, & $\begin{array}{c}\text { Looking at what position the earth depends on how } \\
\text { the rays hit th moon }\end{array}$ \\
а Земля так же вращается вокруг Солнца, & \\
небольшие промежутки времени лучи падают на & $\begin{array}{l}\text { Луну. Если Луна скрылась за Землей, то лучи на } \\
\text { нее не падают }\end{array}$ \\
(Translation: Because the Moon orbits the Earth, and \\
the Earth also revolves around the Sun, small inter- \\
vals of time the rays fall on the Moon. If the Moon \\
hid behind the Earth, then the rays don't fall on it.)
\end{tabular}




\section{Excerpt 2}

\begin{tabular}{|c|c|}
\hline Pre-test & Post-test \\
\hline $\begin{array}{l}\text { В пасмурный день мы смотрим на небо там темно, } \\
\text { луны нет. Через некоторое время узнаём что её } \\
\text { закрыли тучи и постепенно небо освещается, } \\
\text { видим звезды. Бывают полнолуния когда луна } \\
\text { кажется очень близко и очень яркая } \\
\text { (Translation: In a cloudy day we look in the sky it is } \\
\text { dark there, no Moon. After a while we learn that } \\
\text { it was covered by the clouds and gradually the sky } \\
\text { brightens, we see stars. There are eclipses when the } \\
\text { Moon seems very close and very bright.) }\end{array}$ & $\begin{array}{l}\text { Moon has } 7 \text { phaces. I draw theys. When sun shines } \\
\text { fall to the moon and he is changing every day and } \\
\text { shape also }\end{array}$ \\
\hline
\end{tabular}

supplementing her answer with visualisation (her drawing of the model), one of the attributes of the science disciplinary literacy (Goldman et al. 2016; Shanahan and Shanahan 2008; Spires et al. 2018).

Excerpt 3 provides an example from another student, who was working on a Moon phases video and was initially more proficient in English than the students whose examples were given above. The transition from Level 3 to Level 4 on SOLO taxonomy is evident as in the post-test the student demonstrated a more concise use of language via the effective use of terminology and exclusion of redundancy (Excerpt 3). Whereas in her pre-test answer this student wrote an additional sentence that simply restated the idea of the previous sentence and did not provide any new information. This example suggests that the student possessed an alternative conception about the phases of the Moon on the pre-occasion. This alternative conception is commonly called the "eclipse conception" or "shadow of the Earth" and this appears to have been changed to the correct and concise explanation in the post-test response. Conciseness is another feature of science disciplinary literacy (Spires et al. 2018). Indeed, this is what most of the students attained in these two Groups scoring a 4 or 5 on the SOLO taxonomy in their post-test answers.

Table 3 shows that the total of written responses for the four Moon phases questions in English by the end of the intervention in the Kyrgyzstani case increased from 49 to 63 while the total of written responses in Russian remained the same (34). Overall, the number of non-responses reduced from 37 to 23 .

\section{Excerpt 3}

\begin{tabular}{ll}
\hline Pre-test & Post-test \\
\hline $\begin{array}{l}\text { Since the moon circulates around the earth, the } \\
\text { shadow of the earth on the moon changes too, } \\
\text { and we only see the parts of the moon that the sun } \\
\text { rays reach. The dark parts we don't see are the } \\
\text { parts where the sun rays are blocked by the earth }\end{array}$ & $\begin{array}{c}\text { The way the moon looks to us (the phases) depend on } \\
\text { the angle of the sun }\end{array}$ \\
\hline
\end{tabular}


Table 3 Frequency of occurrence of Kyrgyzstani students' responses by language

\begin{tabular}{|c|c|c|c|c|c|c|c|c|c|c|}
\hline & \multicolumn{4}{|c|}{ Pre-test } & \multirow[b]{2}{*}{ Totals } & \multicolumn{4}{|c|}{ Post test } & \multirow[b]{2}{*}{ Totals } \\
\hline & Q3 & Q6 & Q13 & Q14 & & Q3 & Q6 & Q13 & Q14 & \\
\hline Nothing Written & 4 & 9 & 11 & 13 & 37 & 4 & 3 & 9 & 7 & 23 \\
\hline Russian & 10 & 8 & 8 & 8 & 34 & 10 & 8 & 8 & 8 & 34 \\
\hline English & 16 & 13 & 11 & 9 & 49 & 16 & 19 & 13 & 15 & 63 \\
\hline
\end{tabular}

\section{Discussion}

The aim of the current research was to explore how a DST intervention within a STEMA course impacted EFL students' astronomy disciplinary literacy acquisition in English. It can be concluded that the DST educational technology covaried with a positive influence on EFL students' astronomy disciplinary literacy development in English and on their disciplinary knowledge. By the end of the course, all of the research participants demonstrated a positive change in their post-ADT written responses, often shifting from unistructured to multistructural or relational levels of thinking (Biggs and Collis 1982). The largest gains were obtained by the two Kyrgyzstani groups who were engaged in making videos about Moon phases (Groups 3 and 4). These findings contribute to the research on the role of DST in the enhancement of students' writing (Angay-Crowder et al. 2013; Papadopoulou and Vlachos 2014; Rubino et al. 2018) and STEM disciplinary literacy development (Niemi et al. 2018).

Within this study, scientific inquiry has a positive effect on students' learning. However, students who were engaged in inquiry tasks that did not include DST about Moon phases (Groups 1, 2, and 5) did not achieve the same magnitude of the gains as students who were engaged in making videos about Moon phases (Groups 3 and 4). As shown in Fig. 1, students' concept acquisition covaried significantly with the use of DST.

In their responses, all participants attempted to answer more questions in their ADT on the post-test occasion than during the pre-test. There was an increase in English language use by Kyrgyzstani students, while the number of responses in Russian remained the same and the number of questions with no response reduced. This is an unexpected outcome since the research participants in the Kyrgyzstani groups were not directly instructed to answer the ADT questions in English.

The observed rare use of L1 in EFL students' responses implies two outcomes which require further exploration. First, EFL students had a positive attitude about learning in English and were not worried about attempting responses in English. Second, EFL students developed disciplinary literacy in English and therefore wrote their answers in English to compensate for the lack of knowledge of terminology in their L1.

In order to explore the differences in disciplinary literacy between EFL and native English speakers, SOLO responses from the Kyrgyzstani and Australian samples were compared. The results confirmed the performance gap between native and non-native speakers as a group (Dąbrowska 2019; Hulstijn 2019; Menken 2013), but also revealed that course design could bridge the learning outcomes of students with various levels of target language proficiency. The groups of EFL students making videos about Moon phases attained a significantly higher SOLO scores on their ADT post-test than the Australian and Kyrgyzstani students who participated only in the inquiry activities about Moon phases. 
The positive outcomes of two Kyrgyzstani groups (Groups 3 and 4) suggest that a DST intervention supports EFL students' disciplinary literacy acquisition in English. Of a particular interest in the context of EFL pedagogy are the improvements made by the EFL students (Group 4) with the lowest target language proficiency at the beginning of the course. Group 4 slightly outperformed Group 3, despite both groups being exposed to the same course structure. Group 4 students made the largest improvement in their SOLO scores, even though the participants did not receive any explicit literacy instruction throughout the course. It is possible that this outcome is related to the change of the educational context as Groups 1-3 were enrolled by the educational centre, but Group 4 was recruited by the school. Therefore, while Groups 1-3 met each other only during the intervention, Group 4 students knew each other prior to the intervention. It is possible that Group 4 students might have had more trust in each other due to the strong sense of collaboration and a well-established community of practice (Lave and Wenger 1991) in their school. This may have increased the amount of time they spent on sharing concepts rather than on negotiating collaboration or on developing relationships. Additionally, all Group 4 students were female students, which could have affected their classroom interaction style and reinforced the establishment of the community of practice (Lave and Wenger 1991).

The research outcomes could also be a result of the amount of time spent on video production. Group 4 students worked on their videos throughout the whole course, for approximately 10 out of the $20 \mathrm{~h}$ of the course. Groups1-3 spent only three to five hours on the video component of the course. It is also possible that Group 4's results could be linked to prior knowledge about the Moon, as the Muslim religion follows the lunar calendar; however, this was not explicitly measured in the current research.

The DST educational technology establishes a meaningful and inclusive multimodal learning context (Angay-Crowder et al. 2013; Madrid and Cañado 2018; Cañado 2018; Rubino et al. 2018) that facilitates a community of practice formation (Lave and Wenger 1991; Wegner and Nückles 2015). Since EFL students might have different life experiences and sociocultural backgrounds as well as different proficiencies in the target language, DST becomes a middle ground (Aikenhead 1996; Nakata 2018; Ruddell et al. 2016) for the EFL students' negotiation of the concepts being studied. The videomaking process encourages students to construct shared knowledge (Van Aalst 2009) in order to present their personal conceptual understandings. By assigning EFL students to make a video to explain their understanding of a specific astronomical phenomenon, a teacher is empowering students to own their learning by giving them autonomy and when assigned as a group task, DST creates a context for collaboration among students.

To improve students' conceptual understanding their prior knowledge needs to be adapted to a new context (Wegner and Nückles 2015). In the current study, DST served as a tool for adapting EFL students' prior beliefs and assumptions about STEM-A to a video format. In addition, DST reinforces the development of a community of practice (Lave and Wenger 1991; Wegner and Nückles 2015) by encouraging EFL students to acquire new knowledge from their inquiry experiences and collaboration with other students.

\section{Limitations}

Even though this research overall had a reasonable number of participants from Kyrgyzstan, the number of students in each of the intervention groups was low. Therefore, the main limitation of this research is the small sample size that was treated with a multiple 
case-study design. There were some differences in the interventions as well, which limits the interpretation from the comparison of the two cases. Additionally, the option to use their L1 in the ADT was necessary to maximise paired-cases, but this has implications for the interpretation of differences between responses written in EFL students' L1 compared to English. Finally, the impact of students' gender was not considered in the current data analysis; however, given that the highest gains were attained by Group 3, which predominantly contained female students, and female-only Group 4, further research is needed to incorporate students' gender as an independent variable within the data analysis.

\section{Conclusions}

This study exemplifies how DST could be integrated within STEM-A as an effective educational technology for enhancing EFL students' disciplinary literacy, as this teaching approach has not yet been examined within an EFL context. One of the positive aspects of this study was the relationship building and collaboration among the EFL students that covaried with a shared knowledge construction. Over time, this collaboration evolved into a community of practice. In this study, technology was used as a vehicle to encourage students to communicate and to provide an authentic context for learning.

\section{Implications and further research}

In contrast to some CLIL programmes (Lucietto 2008; Cañado 2018; Yang 2016), the DST intervention emphasises a collaborative learning environment that intentionally shifts the focus from teachers' expertise in subject knowledge to an active inquiry approach that involves students in a construction of shared knowledge. The DST pedagogical approach is a student-centred approach that provides a middle ground for shared knowledge construction between students, which also could be accommodated in CLIL programmes. Therefore, the teacher should be ready to enter a community of practice with their students and engage in disciplinary knowledge construction together with the students. The multimodal nature of the DST educational technology aligns with the integration of technology in STEM-A, and thus has the potential to be used in order to create an authentic learning context for all students, regardless of their background.

Further research is needed to explore the effect of the DST intervention on disciplinary literacy development with native-speakers of English. The role of students' gender in DST collaboration is also unclear and requires further investigation. Finally, this research poses a question of disciplinary literacy transferability between EFL students' native and foreign languages.

Acknowledgements The research reported here was supported by the Australian Commonwealth and funded through the International Postgraduate Research Scholarship, Edith Cowan University, Perth, Western Australia. The authors are grateful to the journal editors, anonymous reviewers, all participants, and Edith Cowan University for making their valuable contribution to this research.

Author contributions All authors contributed to the study conception and design. Material preparation and data collection were performed by NC; data analysis was performed by NC, JEM, DHM, and EVS. The first draft of the manuscript was written by $\mathrm{NC}$ and all authors commented on previous versions of the manuscript. All authors read and approved the final manuscript. 


\section{Complaince with ethical standards}

Conflict of interest The authors declare that they have no conflict of interest.

Ethical approval All procedures performed in studies involving human participants were in accordance with the ethical standards of the Ethics in Human Research Committee (HREC) at Edith Cowan University and with the 1964 Helsinki declaration and its later amendments or comparable ethical standards.

Informed consent Informed consent was obtained from all individual participants included in the study as well as from their parents as required by the Ethics in Human Research Committee at Edith Cowan University where the first author was enrolled as a PhD student.

Open Access This article is licensed under a Creative Commons Attribution 4.0 International License, which permits use, sharing, adaptation, distribution and reproduction in any medium or format, as long as you give appropriate credit to the original author(s) and the source, provide a link to the Creative Commons licence, and indicate if changes were made. The images or other third party material in this article are included in the article's Creative Commons licence, unless indicated otherwise in a credit line to the material. If material is not included in the article's Creative Commons licence and your intended use is not permitted by statutory regulation or exceeds the permitted use, you will need to obtain permission directly from the copyright holder. To view a copy of this licence, visit http://creativecommons.org/licenses/by/4.0/.

\section{References}

Australian Curriculum, Assessment and Reporting Authority. (2018). V8.4 F-10 curriculum. Retrieved November 23, 2018 from https://www.australiancurriculum.edu.au/f-10-curriculum/learning-3-6/.

Aikenhead, G.S. (1996). Toward a first nations cross-cultural science and technology curriculum. In Proceedings from the International Organisation of Science and Technology Education Conference. Alberta, Canada.

Aikenhead, G. S. (1998). Many students cross cultural borders to learn science: Implications for teaching. [Abridged version of a keynote address given at CONASTA 47 (Darwin)]. Australian Science Teachers Journal, 44(4), 9-12.

Anderson, J., Chung, Y., \& Macleroy, V. (2018). Creative and critical approaches to language learning and digital technology: Findings from a multilingual digital storytelling project. Language and Education, 32(3), 195-211. https://doi.org/10.1080/09500782.2018.1430151.

Angay-Crowder, T., Choi, J., \& Yi, Y. (2013). Putting multiliteracies into practice: Digital storytelling for multilingual adolescents in a summer program. TESL Canada Journal, 30(2), 36-45.

Arno-Macia, E., \& Mancho-Bares, G. (2015). The role of content and language in content and language integrated learning (CLIL) at university: Challenges and implications for esp. English for Specific Purposes, 37(1), 63-73. https://doi.org/10.1016/j.esp.2014.06.007.

Bell, P., Lewenstein, B., Shouse, A. W., \& Feder, M. A. (Eds). (2009). Learning science in informal environments: People, places, and pursuits. Retrieved September 15, 2018 from https://www.nap.edu/catal og.php?record_id=12190.

Biggs, J. B., \& Collis, K. F. (1982). Evaluating the quality of learning. The SOLO taxonomy (Structure of the Observed Learning Outcome). New York: Academic Press.

Cañado, M. (2018). CLIL and pedagogical innovation: Fact or fiction? International Journal of Applied Linguistics, 28(3), 369-390. https://doi.org/10.1111/ijal.12208.

Castañeda, M., Shen, X., \& Claros Berlioz, E. (2018). This is my story: Latinx learners create digital stories during a summer literacy camp. TESOL Journal, 9(4), 1-14.

Chubko, N., Morris, J. E., McKinnon, D. H., Slater, E. V., \& Lummis, G. W. (2019). Engaging adolescent Kyrgyzstani EFL students in digital storytelling projects about astronomy. Issues in Educational Research, 29(4), 1107-1130.

Dąbrowska, E. (2019). Experience, aptitude, and individual differences in linguistic attainment: A comparison of native and nonnative speakers. Language Learning, 69(S1), 72-100. https://doi.org/10.1111/ lang.12323. 
Darío, L. (2014). An investigation into CLIL-related sections of EFL coursebooks: Issues of CLIL inclusion in the publishing market. International Journal of Bilingual Education and Bilingualism, 17(3), 345-359. https://doi.org/10.1080/13670050.2013.793651.

Department of the Prime Minister and Cabinet (2018). Closing the Gap: Prime Minister's report- 2018.

Díaz Pérez, W., Fields, D., \& Marsh, D. (2018). Innovations and challenges: Conceptualizing CLIL practice. Theory into Practice, 57(3), 177-184. https://doi.org/10.1080/00405841.2018.1484037.

Fleckenstein, J., Leucht, M., Pant, H., \& Köller, O. (2016). Proficient beyond borders: Assessing nonnative speakers in a native speakers' framework. Large-Scale Assessments in Education. https://oi. org/10.1186/s40536-016-0034-2.

Fujimoto-Adamson, N., \& Adamson, J. (2018). From EFL to EMI: Hybrid practices in English as a medium of instruction in Japanese tertiary contexts. In Y. Kırkgöz \& K. Dikilitaş (Eds.), Key issues in english for specific purposes, english language education (pp. 201-221). Cham, Switzerland: Springer.

Goldman, S., Britt, M., Brown, W., Cribb, G., George, M., Greenleaf, C., et al. (2016). Disciplinary literacies and learning to read for understanding: A conceptual framework for disciplinary literacy. Educational Psychologist, 51(2), 219-246.

González-Howard, M., \& McNeill, K. (2016). Learning in a community of practice: Factors impacting English-learning students' engagement in scientific argumentation. Journal of Research in Science Teaching, 53(4), 527-553. https://doi.org/10.1002/tea.21310.

González-Howard, M., McNeill, K., Marco-Bujosa, L., \& Proctor, C. (2017). 'Does it answer the question or is it French fries?': An exploration of language supports for scientific argumentation. International Journal of Science Education, 39(5), 528-547. https://doi.org/10.1080/09500 693.2017.1294785.

Grandinetti, M., Langellotti, M., \& Ting, Y. (2013). How CLIL can provide a pragmatic means to renovate science education-even in a sub-optimally bilingual context. International Journal of Bilingual Education and Bilingualism, 16(3), 354-374. https://doi.org/10.1080/13670050.2013.777390.

Haydock, K. (2011). Why do we have problems learning and teaching science? Contemporary Education Dialogue, 8(2), 257-262. https://doi.org/10.1177/097318491100800211.

Hulstijn, J. (2019). An individual-differences framework for comparing nonnative with native speakers: Perspectives from BLC theory. Language Learning, 69, 157-183. https://doi.org/10.1111/ lang.12317.

Jendrych, E. (2013). Developments in ESP Teaching. Studies in Logic, Grammar and Rhetoric, 34(1), 43-58.

Lave, J., \& Wenger, E. (1991). Situated learning: Legitimate peripheral participation (Learning in doing). Cambridge England: Cambridge University Press.

Lucietto, S. (2008). A model for quality CLIL provision. International CLIL Research Journal, 1(1), 83-92. Retrieved from: http:/www.icrj.eu/index?vol=11\&page $=746$.

Madrid, D., \& Cañado, M. (2018). Innovations and challenges in attending to diversity through CLIL. Theory into Practice, 57(3), 241-249.

McKinnon, D. H. (2013). A journey through space and time (4th ed.). Bathurst, Australia: Charles Sturt University.

McKinnon, D., \& Geissinger, H. (2002). Interactive astronomy in elementary schools. Educational Technology \& Society, 5(1), 124-128.

Menken, K. (2013). Emergent bilingual students in secondary school: Along the academic language and literacy continuum. Language Teaching, 46(4), 438-476.

Mercieca, B. (2017). What is a community of practice? In J. McDonald \& A. Cater-Steel (Eds.), Communities of practice: Facilitating social learning in higher education (pp. 3-26). Singapore: Springer.

Meyer, X., \& Crawford, B. (2015). Multicultural inquiry toward demystifying scientific culture and learning science. Science Education, 99(4), 617-617.

Morgan, H. (2015). Creating and using podcasts promotes student engagement and learning. Childhood Education, 91(1), 71-73.

Morton, T. (2018). Reconceptualizing and describing teachers' knowledge of language for content and language integrated learning (CLIL). International Journal of Bilingual Education and Bilingualism, 21(3), 275-286. https://doi.org/10.1080/13670050.2017.1383352.

Nakata, M. (2018). Difficult dialogues in the south: Questions about practice. The Australian Journal of Indigenous Education, 47(1), 1-7. https://doi.org/10.1017/jie.2017.22.

National Assessment Program. (2015). National assessment program: Literacy and Numeracy. Achievements in reading, persuasive writing, language conventions and numeracy. Retrieved March 15, 2016 from https://www.nap.edu.au/results-and-reports. 
Niemi, H., Niu, S., Vivitsou, M., \& Li, B. (2018). Digital storytelling for twenty-first-century competencies with math literacy and student engagement in China and Finland. Contemporary Educational Technology, 331-353, 331-353. https://doi.org/10.30935/cet.470999.

Ohler, J. (2013). Digital storytelling in the classroom: New media pathways to literacy, learning, and creativity (2nd ed.). Thousand Oaks, CA: Corwin Press.

Papadopoulou, S., \& Vlachos, K. (2014). Using digital storytelling to develop foundational and new literacies. Research Papers in Language Teaching and Learning, 5(1), 235-258.

Pirbhai-Illich, F. (2010). Aboriginal students engaging and struggling with critical multiliteracies. Journal of Adolescent and Adult Literacy, 54(4), 257-266.

Pirbhai-Illich, F., Turner, K. C., \& Austin, T. (2009). Using digital technologies to address Aboriginal adolescents' education: An alternative school intervention. Multicultural Education \& Technology Journal, 3(2), 144-162.

Plo-Alastrué, R., \& Pérez-Llantada, C. (Eds.). (2015). English as a scientific and research language: Debates and discourses. vol. 2, Berlin, Germany: De Gruyter Mouton.

Rossiter, M., \& Garcia, P. (2010). Digital storytelling: A new player on the narrative field. New Directions for Adult \& Continuing Education, 2010, 37-48.

Rubino, I., Barberis, C., \& Malnati, G. (2018). Exploring the values of writing collaboratively through a digital storytelling platform: A mixed-methods analysis of users' participation, perspectives and practices. Interactive Learning Environments, 26(7), 882-894. https://doi.org/10.1080/10494 820.2017.1419499.

Ruddell, N., Danaia, L., \& McKinnon, D. (2016). Indigenous sky stories: Reframing how we introduce primary school students to astronomy-A type II case study of implementation. The Australian Journal of Indigenous Education, 45(2), 170-180. https://doi.org/10.1017/jie.2016.21.

Shanahan, T., \& Shanahan, C. (2008). Teaching disciplinary literacy to adolescents: Rethinking contentarea literacy. Harvard Educational Review, 78(1), 40-59.

Slater, E., Morris, J., \& McKinnon, D. (2018). Astronomy alternative conceptions in pre-adolescent students in Western Australia. International Journal of Science Education, 40(17), 2158-2180. https:// doi.org/10.1080/09500693.2018.1522014.

Smith, R., Kuchah, K., \& Lamb, M. (2018). Autonomy in language learning and teaching: New research agendas. In Learner autonomy in developing countries (pp. 7-27). London, England: Palgrave Macmillan.

Somers, T. (2017). Content and language integrated learning and the inclusion of immigrant minority language students: A research review. International Review of Education, 63(4), 495-520. https:// doi.org/10.1007/s11159-017-9651-4.

Spires, H., Kerkhoff, S., Graham, A., Thompson, I., \& Lee, J. (2018). Operationalizing and validating disciplinary literacy in secondary education. Reading and Writing: An Interdisciplinary Journal, 31(6), 1401-1434.

Stevenson, A. (2015). "Why in This Bilingual Classroom ... Hablamos Más Español?" Language choice by bilingual science students. Journal of Latinos and Education, 14(1), 25-39. https://doi. org/10.1080/15348431.2014.944704.

Tang, K., \& Danielsson, K. (Eds.). (2018). Global developments in literacy research for science education. Cham, Switzerland: Springer.

Teehan, K. (2006). Digital storytelling: In and out of the classroom. New York: Lulu Press.

The Nation's Report Card (2015). 2015 science assessment. Retrieved from https://www.nationsreportca rd.gov/science_2015/\#?grade=4.

Tytler, R., Prain, V., \& Hubber, P. (2018). Representation construction as a core science disciplinary literacy. In K. Tang \& K. Danielsson (Eds.), Global developments in literacy research for science education (pp. 301-317). Cham, Switzerland: Springer International Publishing AG.

Van Aalst, J. (2009). Distinguishing knowledge-sharing, knowledge-construction, and knowledge-creation discourses. International Journal of Computer-Supported Collaborative Learning, 4(3), 259287. https://doi.org/10.1007/s11412-009-9069-5.

Wegner, E., \& Nückles, M. (2015). Knowledge acquisition or participation in communities of practice? Academics' metaphors of teaching and learning at the university. Studies in Higher Education, 40(4), 624-643. https://doi.org/10.1080/03075079.2013.842213.

Yang, W. (2016). ESP vs. CLIL: A coin of two sides or a continuum of two extremes? ESP Today, 4(1), 43-68.

Yin, R. K. (2014). Case study research: Design and methods (5th ed.). Los Angeles, CA: SAGE.

Zellner, N. (2018). Video killed the writing assignment. Journal of Astronomy \& Earth Sciences Education (JAESE), 5(2), 137-150. https://doi.org/10.19030/jaese.v5i2.10222. 
Zhang, Y. (2016). Multimodal teacher input and science learning in a middle school sheltered classroom. Journal of Research in Science Teaching, 50(1), 7-30.

Publisher's Note Springer Nature remains neutral with regard to jurisdictional claims in published maps and institutional affiliations.

Dr. Nadezhda Chubko has completed her PhD in Education with Edith Cowan University, Australia. Her areas of interest and research include curriculum materials and design, TESOL, ICT, gender and education, multilingual education, and disciplinary literacy

Dr. Julia E. Morris currently works within the School of Education at Edith Cowan University. Julia is primarily a mixed methods researcher with an interest in the area of students' engagement with learning and teachers' engagement with the profession, and in creative arts research as a visual artist and educator.

Dr. David H. McKinnon is an Adjunct Professor of Education at Edith Cowan University, Australia. He established and ran the Charles Stuart University Remote Telescope until July 2014. He has a profound interest in science education at all levels and especially involving astronomy, public outreach and teacher professional learning.

Dr. Eileen V. Slater currently works within the School of Education at Edith Cowan University. Eileen does research in gifted education, science education and educational assessment.

Dr. Geoffrey W. Lummis is an Associate Professor within the School of Education at Edith Cowan University. His research interests include visual arts in education; aesthetics and the arts in education; primary science education, and sustainability. 